\title{
A TECHNOLÓGIAI FEJLŐDÉS HATÁSA A MUNKAPIACON ELVÁRT KÉSZSÉGEKRE
}

IMPACT OF TECHNOLOGICAL DEVELOPMENT ON

SKILLS EXPECTED IN THE LABOUR MARKET

\section{FAZEKAS KÁROLY ${ }^{1}$}

A technológiai fejlődése során nem csupán a gazdaság ágazati és foglalkozási szerkezete változik. Az egyes foglalkozásokon belül jelentős átalakulás megy végbe a munkafeladatok tartalmában aszerint, hogy azok elvégzése milyen készségeket kíván meg a munkavállalóktól. Az elmúlt években leggyorsabban a matematikai jártasságot és a nem kognitív készségeket egyaránt megkövetelö feladatokat tartalmazó álláshelyek aránya növekedett, és leginkább azon álláshelyek aránya csökkent, melyekben az elvégzendö feladatok jellemzöen sem matematikai jártasságot, sem szociális készségeket nem igényeltek a munkavállalóktól. A cikk bemutatja a nem kognitív készségek definiálásának, mérésének nehézségeit. Bemutatjuk a nem kognitívkészségek hatásainak közgazdasági elemzésében elért eredményeket és összefoglaljuk a nem kognitív készségek felértékelödésének okait és munkapiaci következményeit. A tanulmány bemutatja a mesterséges intelligencia alkalmazásának lehetöségét a nem kognitív készségeket igénylö munkakörökben. A tanulmány befejezö részében összefoglaljuk a nem kognitiv készségek fejlesztésének, oktatásának lehetséges módszereit és azok hatását a fiatalok munkaerőpiaci helyzetére.

It is not only the sectoral and occupational structure of the economy that is changing as technology advances. Within each occupation, there is a significant shift in the content of the job assignments according to the skills that the employees need to complete them. In recent years, the share of jobs requiring both mathematical and non-cognitive skills has increased most rapidly, with the highest decline in jobs requiring typically neither mathematical nor social skills. This article presents the difficulty of defining and measuring non-cognitive skills. We present the results of the economic analysis of the effects of non-cognitive skills and summarize the reasons and the labor market consequences of the appreciation of non-cognitive skills. The study presents the possibility of using artificial intelligence in non-cognitive jobs. In the concluding section of the study we summarize the possible ways of developing and educating non-cognitive skills and their impact on the labour market situation of young people

A technológiai fejlődése, a nemzetközi, a regionális és a társadalmi munkamegosztás átalakulása során nem csupán a gazdaság ágazati és foglalkozási szerkezete változik. Az egyes foglalkozásokon belül jelentős átalakulás megy végbe a munkafeladatok tartalmában aszerint, hogy azok elvégzése milyen készségeket kíván meg a munkavállalóktól. David Deming sokat hivatkozott

\footnotetext{
${ }^{1}$ Az MTA emeritus kutatója, KRTK KTI-MTA; egyetemi magántanár, Budapesti Corvinus Egyetem email: fazekas.karoly@krtk.mta.hu

DOI:10.14267/RETP2019.04.02
} 
tanulmánya az USA munkapiaci adatainak elemzése alapján felhívja a figyelmet a foglalkozások elmúlt évtizedekben e tekintetben végbement polarizációjára. Kimutatja, hogy leggyorsabban a matematikai jártasságot és a szociális készségeket egyaránt megkövetelő feladatokat tartalmazó álláshelyek aránya növekedett, és leginkább azon álláshelyek aránya csökkent, melyekben az elvégzendő feladatok jellemzően sem matematikai jártasságot, sem szociális készségeket nem igényeltek a munkavállalóktól. Hasonló polarizáció figyelhető meg a foglalkozási csoportokra jellemző átlagbérek alakulásában is [Deming, 2017].

A matematikai jártasság a kognitív készségek csoportjába tartozik. Kognitív készségek alatt az adott feladatokhoz elvégzéséhez, a felvetődő problémák megoldásához szükséges gondolkodási, tanulási, problémamegoldási készségeket hívjuk. ${ }^{2}$ Ezek munkapiaci felértékelődése régóta ismert jellemzője a korábbi technológiai forradalmakat kísérő szerkezeti átalakulásoknak [Hanusek - Woesmann, 2008; Acemoglu - Author, 2011]. A nem-kognitív, „puha”, szociális készségek az emberek személyiségjegyeihez, temperamentumához, attitüdjeihez kapcsolódnak. A munkahelyen az általunk birtokolt kognitív készségek biztosítják, hogy meg tudjuk tanulni, és az elvárt teljesítménnyel el tudjuk végezni a munkakörünkhöz kapcsolódó feladatokat. A nem-kognitív készségek viszont leginkább ahhoz szükségesek, hogy a munka során sikeresen együtt tudjunk müködni másokkal.

Az elmúlt évtizedekben megfigyelhető a munkapiacon a nem-kognitív készségek felértékelődése. E folyamat oktatási, munkapiaci, társadalmi jelentőségének felismerésében a James Heckman és a Jack P. Shonkoff által vezetett chicagói és harvardi kutatócsoportok ${ }^{3}$ elemzéseinek és szakpolitikai javaslatainak volt a legnagyobb hatása. Heckman, Shonkoff és munkatársai tanulmányaikban már évekkel ezelött felhívták a figyelmet a nem-kognitív készségszinteknek és az fejlesztésükre irányuló beavatkozásoknak az emberek kognitív készségeire, iskolázottsági, munkapiaci és társadalmi helyzetére gyakorolt rövid és hosszú távú pozitív hatásaira [Heckman - Rubinstein, 2001; Heckman és társai, 2006; Shonkoff - Phillips, 2000; Falch és társai, 2014; Shonkoff, 2012].

\section{A NEM-KOGNITÍV KÉSZSÉGEK HATÁSAINAK KÖZGAZDASÁGI ELEMZÉSE}

A nem-kognitív készségek hosszú távú egyéni, társadalmi hatásainak, a készségek fejlesztésére irányuló beavatkozások eredményeinek korrekt közgazdasági elemzését hosszú ideig hátráltatta, hogy jó ideig nem alakult ki egységesen értelmezett nomenklatúra és mérési módszer ezen a területen. Az USA Nemzeti Kutatási Tanácsa (US National Research Council) által 2012-ben kidolgozott klasszifikáció [NRC, 2012] ugyan segített rendet teremteni a definíciók alig áttekinthető rengetegében, de nem elégítette ki a jól működő, azonos módon értelmezett definíciókra építő mérési módszertan iránti igényeket [Humpries és Kosse, 2017].

A kognitív és nem-kognitív készségek meghatározásával és mérésével a Munkaerôpiaci Tükör köteteiben részletesebben foglalkoztunk [Fazekas, 2017, 2018]. Az ott leírtakat azzal egészítjük

\footnotetext{
${ }^{2}$ Ezek például: a szabatos fogalmazás, az értelmező olvasás, a matematikai jártasság, az absztrakciós, logikai készség, és ilyenek a feladatspecifikus motorikus készségek.

${ }^{3}$ The University of Chicago Center for Economics and Human Development. https://cehd.uchicago.edu/. Center on the Developing Child, Harvard University. https://developingchild.harvard.edu/. A James Heckman által vezetett kutatások és kezdeményezések eredményiről jó áttekintést ad a „The Heckman Equation” elnevezésü projekt honlapja: https://heckmanequation.org/.
} 
ki, hogy a magatartáskutatók által kidolgozott, a nem-kognitív készségeket öt csoportba rendező, a szakirodalomban „Big Five”-nak nevezett nomenklatúrát és az azok mérésére használt teszteket ma már nagyon sok közgazdasági elemzés használja. ${ }^{4}$ Ezek a teszteredmények számos hosszú távú követéses vizsgálatba beépültek, így lehetöséget adnak a különböző életkorokban elvégzett tesztek eredményeinek és az életút különböző jellemőzinek összekapcsolására ${ }^{5}$ [Segal, 2013]. Bár a tesztekben használt kérdések hasonlóan müködnek nagyon eltérő kulturális háttérrel rendelkező csoportokban, ez a módszer sem tudja kizárni az értékelést/önértékelést végző személyek szubjektív torzításait. A mérési és definíciós hiányosságok ellenére napjainkra - a pszichológia és a közgazdaságtan határterületén mozgó interdiszciplináris elemzéseknek is köszönhetően az ember pszichológiai készségeinek mérése, hatáselemzése az emberi tőkével foglalkozó közgazdasági szakirodalom meghatározó területe lett [Kautz et al., 2017; Brunello-Schlotter, 2011; Thiel- Thomsen, 2011].

Viszonylag új fejlemény ezen a területen a "Gondolatolvasás Szemekből Teszt" (Reading in the Mind in the Eyes Test, RMET) elnevezésü, eredetileg autista betegek kiszürésére kidolgozott, az ember mentalizációs képességeinek értékelésére alkalmas módszer [Baron-Cohen és társai, 2001] felhasználása nem-kognitív készségszintek mérésére. ${ }^{6}$ Az ember mentalizációs készsége (Theory of Mind, ToM) alatt azt értjük, hogy másokat megfigyelve képesek vagyunk belehelyezkedni mások nézőpontjába, megértjük, és saját céljaink, cselekedeteink szempontjából értékelni tudjuk mások cselekedeteinek okait, érzelmi állapotának jellemzőit. A mentalizációs képesség az oktatásban és a munkapiacon egyaránt kiemelkedően fontos a kétoldalú és csoportos kooperációk sikere szempontjából [DeAngelo-McCannon, 2015]. Az RMET felhasználásával végzett vizsgálatok eredményeire támaszkodó elemzések azt mutatják, hogy a módszer nem csupán arra alkalmas, hogy az arckifejezésekből a megfigyelt személyek mentális állapotára való következtetés pontosságát mérjük vele. A teszteredmények jó proxy változói a válaszadók empatikus képességeinek, érzelmi intelligenciájának, kooperációs készségeinek [Engel és társai, 2014].

Lundberg [2018] három tényezővel magyarázza a nem-kognitív készségek jelentőségének gyors növekedését az emberi tőkével foglalkozó közgazdasági irodalomban: a) annak felismerése, hogy a nem-kognitív készségek minősége meghatározó, és az utóbbi évtizedekben növekvő hatással van az iskolai és munkapiaci sikerességre; b) megbízható mérési módszerek elterjedése; c) a nem-kognitív készségek iskolai, munkahelyi fejlesztésére irányuló beavatkozások eredményességére vonatkozó ismeretek bővülése. A nem-kognitív készségek iskolai és munkapiaci felértékelődése egymással szorosan összefüggő technológiai és demográfiai okokkal magyarázható. A robotizációnak, a mesterséges intelligencia (MI) fejlődésének és egyre szélesebb körben történő felhasználásának, az egymással folyamatosan kommunikáló elemekből álló termelési, szolgáltatási rendszerek (Internet of Things) terjedésének eredményeképpen a magas szintü kognitív készségeket igénylő feladatok mind nagyobb részét el tudják végezni intelligens, számítógépek

\footnotetext{
${ }^{4}$ Az NRC (2012) által használt nomenklatúra viszonylag homogén csoportokba rendezi a nagyon eltérő nemkognitív készségeket, és összhangot teremt az általa kidolgozott és a BIG5 által használt definíció között.

${ }^{5}$ Mint például a szabadságvesztés, munkanélküliség, dohányzás, kábítószer-használat, betegségben, egészségben töltött élettartam, karrier, életkereset.

${ }^{6}$ A tesztet saját mentalizációs készségszintünk értékelésére is alkalmazhatjuk, lásd: https://well.blogs.nytimes.com/2013/10/03/well-quiz-the-mind-behind-the-eyes/
} 
által vezérelt eszközök. A robotizáció terjedése azonban mindeddig kevéssé volt jellemző a nemkognitív készségeket igénylő munkakörökben. Ugyanakkor e munkakörök aránya folyamatosan növekszik a munkapiacon a szolgáltatások arányának növekedése, valamint - a növekvő átlagéletkorral párhuzamosan - az ápolási, egészségügyi álláshelyek arányának növekedése miatt. Továbbá a korszerü vállalati menedzsment müködésében is egyre fontosabb szerepe van a csoportmunkára, bizalomra, intuitív gondolkodásra, társadalmi készségekre épülő munkafeladatoknak [Schanzenbach és társai, 2016].

A legutóbbi időkig a témával foglalkozó szakirodalomra - az álláshelyek eltűnésének apokaliptikus látképét felrajzoló sajtócikkek ellenére - inkább az álláshely rombolás és építés folyamatának pozitív egyenlegét felvázoló jövőkép volt jellemző. A régi foglalkozások és álláshelyek egy része valóban eltűnik, akár néhány éven belül, de közben új foglalkozások és állások keletkeznek, és bizonyos, leginkább nem-kognitív készségeket igénylő foglalkozásokban folyamatosan növekszik a munkaerő kereslete. A szakértői optimizmusnak részben az volt a magyarázata, hogy miközben gyorsan nő a nem-kognitív készségeket igénylő állások száma a munkapiacon, addig a mesterséges intelligenciára építő technológiai fejlesztések kevéssé érintik ezeket a munkaköröket. Sokáig úgy tűnt, a mesterséges intelligencia nem alkalmas nem-kognitív készségek elsajátítására, fejlesztésére.

A legutóbbi években azonban fontos elörelépések történtek ezen a területen is. (Lásd keretes írásunkat.) A három legfontosabb kihívás a szociális intelligenciával rendelkező mesterséges intelligencia megalkotása területén a következö: 1) képesség a társadalmi dinamikák modellezésére; 2) képesség a társadalmi és morális normák elsajátítására; 3 ) mentalizációs képességek kifejlesztése [Yang és társai, 2018]. Az utóbbi hónapokban egyre több ismeretünk van arról, hogy a mesterséges intelligencia is felruházható mentalizációs képességekkel Revell, 2018; Lu, 2019]. A legújabb fejlesztések eredményeit figyelembe vevő előrejelzések szerint a következő évtizedekben a személyi szolgáltatások széles körében, a beteg, idős emberek ápolásában, a gyógyításban, kereskedelemben, a kreatív iparágakban a nem-kognitív készségekkel rendelkező robotok egyre nagyobb arányban képesek lesznek elvégezni a megkívánt feladatokat [Morgan és társai, 2019].

Tekintettel a robotizáció - már napjainkban is zajló - térnyerésére különösképpen szükséges, hogy a fiatalok rendelkezzenek olyan készségekkel, melyek szükségesek a változó készségigényekhez való alkalmazkodáshoz, rendelkezzenek új készségek megtanulásához szükséges motivációval és képességekkel. Folyamatosan szükség van olyan elemző munkára is, amely feltárja az adott munkaerőpiacon végbemenő változásokat, segíti a képzési, oktatási rendszer fejlesztőit, hogy a tananyag és az oktatási módszertan fejlesztésével maguk is alkalmazkodjanak a változásokhoz [Alabdulkareem és társai, 2018]. Bár a nem-kognitív készségek jelentős része örökletes tulajdonságokhoz kötődik, számos empirikus elemzés bizonyítja, hogy a szülők, a lakókörnyezet és az iskola jelentős mértékben képesek fejleszteni, alakítani ezeket a készségeket [Zhou, 2016]. A nem-kognitív készségek fejlesztésére szolgáló módszerek (például csoportmunkára építő projekt alapú oktatás) mind több ország iskolarendszerének tantervébe beépülnek. Azok eredményességének mérését szolgálják az OECD PISA és a Világbank STEP felméréseibe 2012 óta beépített kérdések [Kautz és társai, 2017; Gaelle és társai, 2014].

Azonban a robotizáció nem-kognitív készségeket igénylö munkakörökben való elterjedésének fontos előfeltétele, hogy ne csak az MI értse az emberek viselkedését. Fontos, hogy a mesterséges intelligencia döntései és viselkedése megérthető, megmagyarázható legyen. A Megmagyarázható Mesterséges Intelligencia (MMI) kifejlesztésének előfeltétele, hogy a gyakorlatban a mindennapi életben bizalom alakuljon ki az MI és az MI-t használó emberek között. 


\section{Mentalizációs képességekkel rendelkező Megmagyarázható Mesterséges Intelligencia (MMI) fejlesztése}

2017. májusában a „Go Jövője” elnevezésű nemzetközi konferencián a Google DeepMind által kifejlesztett AlfaGo nevü program egy hárommenetes játszmában legyőzte Ke Jie 9 danos nagymestert, akit a világ legjobb Go játékosának tartottak, majd két menetben legyőzte a legjobb kínai professzionális Go játékosokból válogatott ötfős csapatot. Ezek után a kínai Go játékosokat összefogó kínai Weiqi Association 9 danos nagymesteri címet adományozott az AlfaGo mesterséges intelligenciának. A Go - hasonlóan a sakkhoz - egyéni stratégiai gondolkodáson és jelentős mértékben intuíción alapuló játék. Nyilvánvaló, hogy ezen a területen az MI képességei már meghaladják az emberi agy képességeit.

Az ember azonban társadalmi lény, sikerének titka jelentős mértékben abban van, hogy képes egymással kooperáló egyénekből álló csoportokban dolgozni. Ezt felismerve az Elon Musk által támogatott OpenAI nonprofit kutatóvállalat elhatározta, hogy kifejleszt egy öt önálló MI kooperációjára épülő csapatot, amelynek tagjait felkészítik arra, hogy részt vegyenek az évente megrendezendő Dota 2 Nemzetközi Bajnokságon. A Dota 2 egy komplex stratégiai játék, amelyben két ötfős csapat játszik, és a csapatok sikere nagymértékben függ a játékosok kooperációs készségeitől. A 2018. augusztusában Vancouverben rendezett bajnokságon az OpenAI Five végül alulmaradt a legjobb Dota 2 játékosokból válogatott csapattal szemben. Akkor még úgy tünt, hogy a kooperációra, a csapatjátékosok mentalizációs képességeire épülő stratégiai gondolkodásban az emberi agy még felülmúlja az MI képességeit [Fan, 2018]. A 2019. évi világbajnokságon azonban az OpenAI Five legyőzte a 2018. évi OG elnevezésű világbajnok csapatot. Az elmúlt két év kutatási eredményei azt mutatják, hogy a mesterséges intelligencia valószínűleg felruházható mentalizációs képességekkel. Az egyik fejlesztési lehetőség a szimulációs technológia [Winfield, 2018]. Ennek a technológiának lényegi eleme az, hogy a mesterséges intelligenciát felruházzák az emberi agyhoz hasonló azon képességgel, hogy az adott szituációban saját és mások várható viselkedését koherens történetbe tudja rendezni. A tanulmányban bemutatott kísérletek igazolták ennek a lehetőségét.

A másik lehetőség a gépi tanulás (Deep Learning) továbbfejlesztése. 2018-ban a Google által finanszírozott DeepMind Projekt keretében elindították egymással kooperáló, mentalizációs képességekkel (ToM) rendelkező mesterséges intelligenciák fejlesztését. A projekt keretében kifejlesztettek egy ToMnet nevü algoritmust, amely képes tanulni más mesterséges intelligenciák döntéseiből. A ToMnet valójában három neurális háló kooperációja. Az első képes más MI-k jellemző viselkedési mintáinak rögzítésére azok korábbi döntéseinek elemzésével. A második képes koherens fogalmat alkotni más MI-k aktuális elmeállapotáról (hitek, intenciók). A harmadik neurális háló az első kettő eredményei alapján meghatározza a ToMnet döntéseit az aktuális szituációkban. A ToMnet különlegesen fontos tulajdonsága, hogy képes tanulni mások viselkedéséből, de még korai kijelenteni, hogy rendelkezik mesterséges mentalizációs képességgel. Jelenleg a ToMnet és a hozzá hasonló MI-k mentalizációs képessége nagyon kötődik ahhoz a környezethez, kontextushoz, amelyben a tanulási folyamat zajlik. Teljesen új környezetben - ellentétben például a négyéves kort elért gyerekekkel - már sokkal kevésbé képes mások, más mesterséges intelligenciák viselkedésének megértésére, előrejelzésére. A DeepMind ToMnet projektje és a hozzá hasonló fejlesztések nemcsak azért fontosak, hogy az MI-k megértsék az ember viselkedését, hanemazért is, hogy mi is megértsük az MI-k viselkedését. Ez nem csupán a fejlesztők számára fontos szempont. Minél inkább szerves részei a mesterséges intelligencia által irányított eszközök az életünknek, annál fontosabb, hogy a felhasználók, a szabályozók, a döntéshozók tisztában legyenek viselkedésük alapelveivel. [Thampi, 2019; Hutson, 2018; Rabinowitz és társai, 2018; Revell, 2018] 


\section{A NEM-KOGNITÍV KÉSZSÉGEK OKTATÁSA}

Felmerül a kérdés: ha a folyamatok ilyen rohamléptekkel zajlanak és ilyen mértékben kiszámíthatatlan a technológiai fejlődés üteme és iránya, hogyan kell felkészíteni a fiatalokat arra, hogy megfeleljenek a munkapiacon 10-20 év múlva elvárt készségeknek? Az iskola feladata nyilvánvalóan nem lehet a még nem is ismert konkrét ismeretek és munkafeladatok megtanítása, betanítása. Az iskolának egyrészt fel kell ruháznia a diákokat a konkrét munkafeladatok által igényelt tudás későbbi elsajátításához szükséges kognitív készségekkel. Ezek jelentősége várhatóan erősödik a következő évtizedekben [Fayer és társai, 2017; Deming-Noray, 2018]. Egyre több empirikus elemzés támasztja alá azt a tényt, hogy az iskolai sikerességben a nem-kognitív készségeknek legalább olyan nagy szerepük van, mint az oktatás során elsajátított kognitív készségeknek [Segal, 2013; Brunello-Schlotter, 2011; Urvashi-Singh, 2017]. Ezekkel a készségekkel jelentős részben már az iskolába belépve rendelkeznie kellene a gyerekeknek. Mind több ismeretünk van arról, hogy a nem-kognitív készségek fejlödésében az öröklött készségek mellett meghatározó szerepük van a koragyerekkori hatásoknak, mindenekelött a szülői nevelésnek és a toxikus streszsztöl mentes családi, lakóhelyi környezetnek [Shonkoff - Philips, 2000; Olson, 2012]. Ugyanakkor számos kutatási eredmény bizonyítja, hogy a megfelelően felépített, a szülői nevelést is támogató, a nem-kognitív készségeket erősítését célzó koragyerekkori és iskoláskori fejlesztési programoknak tartós, pozitív hatásuk van az iskolai teljesítményekre, a továbbtanulási esélyekre, sőt, a munkaerőpiacon elért sikerességre is [AAP, 2013; Falch és társai, 2014].

Korábban láttuk, hogy az iskolai, munkapiaci siker egyre inkább a magas szintü kognitív és nem-kognitív készségek együttes birtoklását feltételezi. Ennek megfelelően az iskolának a tanulók életkorához alkalmazkodó módszereket kell alkalmazni egyrészt a STEM készségek kifejlesztésére másrészt a nem-kognitív készségek továbbfejlesztésére. Mint tudjuk: „készség készséget szül” [Heckman, 2008]. Az adott életkorban elsajátított tudásra, készségekre épülnek a későbbi életkorban elsajátítható ismeretek és készségek. A szakirodalomban számos elemzés mutatja be a 21. században elvárt nem-kognitív készségeket sikeresen fejlesztő iskola jellemzőit [Brunello - Schlotter, 2011; Kautz és társai, 2017]. Négy fontos elemet emelünk ki ezekből az írásokból:

- A fejlett oktatási rendszerekben fokozatosan háttérbe szorul az ismeretek memorizálására és az egyéni tanulási módszerekre épülő oktatás. Mind nagyobb szerepe van a csoportmunkára, eltérő nézőpontok integrálására, a kreatív képességek fejlesztésére építő projektorientált oktatási módszereknek [Farrington és társai, 2012].

- Mind a középiskolai, mind a felsőfokú oktatásban különösen eredményesek azok a kezdeményezések, melyek a bölcsészet, a szabad müvészetek oktatásába és müvelésébe is beleágyazzák a nem-kognitív készségek fejlesztését [Farrington, 2019].

- A nem-kognitív készségek koragyerekkori, iskolai fejlesztésének sikerességében rendkívül nagy szerepe van a pedagógusok minőségének [Araujo és társai, 2016; Rosen és társai, 2010; Rivkin és társai, 2005; Blazar-Kraft, 2017].

- A nem-kognitív készségek fejlesztésére alkalmas speciális oktatási módszerek mellett pusztán az iskolába járás, az iskola közösségében való tanulás, sportolás, szórakozás, bizonyos feladatok közös elvégzése fontos szerepet játszik a nem-kognitív készségek fejlesztésében. Ezért különösképpen fontosak azok a jogi, pedagógiai eszközök, melyekkel csökkenteni lehet a középfokú oktatásból való kibukás mértékét [Heckman és társai, 2014]. 


\section{A NEM-KOGNITÍV KÉSZSÉGEK SZEREPE A FIATALOK MUNKAPIACRA VALÓ SIKERES BELÉPÉSÉBEN}

Az iskola elvégzése után a munkaerőpiacra való belépés az életút különösképpen kritikus szakasza. A munkát keresőknek meg kell találniuk a számukra megfelelő állásokat és meg kell felelniük a munkáltató által elvárt követelményeknek. Számos olyan elemzés van, amely a munkaeröpiacon leginkább keresett készségek szempontjából mutatja be a nem-kognitív készségek sikeres fejlesztési módszereit. Guerra és társai [2014] egy a kifejezetten a munkaerőpiac által igényelt, nem-kognitív készségek fejlesztésére a Világbank által kidolgozott PRACTICE model alapján ismerteti, hogy a különböző életkori csoportokban milyen módszerekkel lehet legsikeresebben fejleszteni ezeket a készségeket.

Noha a nem-kognitív készségek iskolai fejlesztésében meghatározó szerepe van a pedagógusok módszertani ismereteinek és elkötelezettségének, számos elemzés igazolja a nem-kognitív készségek rendszeres iskolai értékelésének, és az értékeléshez kapcsolódó pedagógiai mentori programoknak a pozitív hatásait [Zernike, 2016; Garcia, 2014]. Bár a nem-kognitív készségek fejlesztésének leghatékonyabb időszaka a koragyerekkor és az iskoláskor, számos olyan nemkognitív készség van, mely egész életünk során fejleszthető [Hoeschler és társai, 2018].

Nagyon fontosak azok az elemzések és kezdeményezések, amelyek a munkaképes korú, az iskolából kikerült fiatalok munkaerőpiacról való kikerülésének, inaktivitásának okaival, integrálásával foglalkoznak. Az eredmények azt mutatják, hogy különösképpen sikeresek azok a programok, amelyek a kognitív készségfejlesztés mellett a nem-kognitív készségek fejlesztésével is foglalkoznak [Guerra-Modecki-Cunningham, 2014]. A készségfejlesztés mellett fontos, hogy a munkavállalók és a munkáltatók egyaránt releváns információkkal rendelkezzenek saját készségszintjükről és a készségek hozamairól. Ezek az információk egyrészt erősítik a munkavállalók motivációját a készségek fejlesztésében, másrészt növelik a munkáltatók készségét a magasabb szintű nem-kognitív készségek honorálásában [Bassi és Nansamba, 2019]. Ma már hatalmas irodalma van a nem-kognitív készségek és a fiatalok munkapiaci sikerei és kudarcai közötti kapcsolat elemzésének. A nem-kognitív készségek mérési nehézségei sok esetben eredetileg más célokra elvégzett mérések kreatív felhasználására késztették a kutatókat. Lindqvist és Vestman [2011] például a svéd hadseregbe besorozandó katonajelöltek pszichológiai alkalmassági tesztjeit felhasználva kimutatták, hogy a mérési eredmények, sőt az interjúkészítőknek a jelöltek idegi állapotáról, idegességéről vagy nyugodtságáról készített érékelései nem pusztán azok katonai alkalmasságának, de későbbi munkapiaci eredményességének is jó előrejelzői voltak.

A globalizálódó gazdaság, a globalizálódó munkapiac igényli, hogy a fiatalok jártassággal rendelkezzenek azokon a területeken, amelyek a globális munkapiacon való sikeres szereplést biztosítják. Ilyen nem-kognitív készség például az eltérő kultúrával, identitással rendelkezőkkel való sikeres együttmüködés képessége. Nemzetközi közösségi akciók, diákcsereprogramok, a külföldi tanulást és munkavállalást, valamint a hazafelé irányuló migrációt támogató kezdeményezések támogathatják ezt a folyamatot. A jelek szerint a munkáltatók jelentős része felismerte a nem-kognitív készségek szerepét a sikeres munkavégzésben. A munkáltatók állásajánlatait és felvételi gyakorlatát vizsgáló elemzések eredményei azt mutatják, hogy a nem-kognitív készségek szintje a sikeres álláskeresés legfontosabb prediktora [Hoeschler és Backes-Gellner, 2018]. Számos példa van arra, hogy ahol a vállalatok beépítik a nem-kognitív készségek fejlesztését a vállalati képzési programokba, ott a képzésre fordított költségeknek jelentős termelékenységi hozamai vannak [Adhvaryu és társai, 2017; Groh és társai, 2012]. 


\section{FelHASZnÁlt irodalom}

AAP (2013): Family Pediatrics. Pediatrics, Vol.111, ISSUE Supplement 2. https://pediatrics.aappublications.org/content/111/Supplement_2/1541.long

ACEMOGLU, D. - AUTHOR, D. (2011): Skills, Tasks and Technologies: Implications for Employment and Earnings, Handbook of Labor Economics, 4 (2011), p. 1043-1171.

ADHVARYU, A.-KALA, N.-NYSHADHAM, A. (2018): The Skills to Pay the Bills: Returns to On-thejob Soft Skills Training. NBER Working Paper, No. 24313. https:/www.nber.org/papers/w24313

ALABDULKAREEM, A.-FRANK, M. R.-SUN, L.-ALSHEBLI, B.-HIDALGO, C.-RAHWAN, I. (2018): Unpacking the polarization of workplace skills. Science Advances, 4(7) https:// advances.sciencemag.org/content/4/7/eaao6030.

ARAUJO, M. C. - CARNEIRO, P. M., CRUZ-AGUAYO, Y., SCHADY, N. (2016): Teacher Quality and Learning Outcomes in Kindergarten. Quarterly Journal of Economics. 131(3):141553. doi: 10.1093/qje/qjw016.

BARON-COHEN, S. - WHEELWRIGHT, S., HILL, J., RASTE, Y., PLUMB, I. (2001): The ' 'Reading the Mind in the Eyes" Test Revised Version: A Study with Normal Adults, and Adults with Asperger Syndrome or High-functioning Autism Journal of Child Psychology and Psychiatry. 42(2):241-251. https://www.ncbi.nlm.nih.gov/pubmed/11280420

BASSI-NANSAMBA [2019]: ? Screening and Signaling Non-Cognitive Skills. UCS-INET Research Paper No. 19-08. SSRN. https://papers.ssrn.com/sol3/papers.cfm?abstract_id=3268523

BLAZAR, D. - KRAFT, M. A. (2017): „Teacher and Teaching Effects on Students' Attitudes and Behaviors" Educational Evaluation and Policy Analysis. 39(1), 146-170. doi:10.3102/0162373716670260

BRUNELLO, G. -SCHLOTTER, M. (2011): Non-Cognitive Skills and Personality Traits: Labour Market Relevance and Their Development in Education \& Training Systems, IZA DP No. 5743. http://ftp.iza.org/dp5743.pdf

DEANGELO, G.-MCCANNON, B. C. (2015): Theory of Mind Predicts Cooperative Behavior. West Virginia University College of Business and Economics, Working Paper Series, No. 16-16. https://ideas.repec.org/p/wvu/wpaper/16-16.html.

DEMING, D. (2017): “The Growing Importance of Social Skills in the Labor Market.” The Quarterly Journal of Economics 132(4):1593-1640. o. https://doi.org/10.1093/qje/qjx022.

DEMING, D.-KAHN, L. B. (2018): Skill requirements across firms and labor markets: Evidence from job postings for professionals. Journal of Labor Economics 36:S337-S369

ENGEL, D. - WOOLLEY, A. W. - JING, L. X. - CHABRIS, C. F. - MALONE, T. W. (2014): Reading the Mind in the Eyes or Reading between the Lines? Theory of Mind Predicts Collective Intelligence Equally Well Online and Face-To-Face. PLoS ONE 9(12): e115212. doi:10.1371/journal.pone.0115212.

FALCH, T. - NYHUS, O. H. - STROM, B. (2014): Performance of Young Adults: The Importance of Different Skills, CESifo Economic Studies 60(2):435-462 doi:10.1093/cesifo/ifu005.

FAN, S. (2018): Thinking Like a Human: What It Means to Give AI a Theory of Mind? https:// singularityhub.com/2018/09/19/thinking-like-a-human-what-it-means-to-give-ai-a-theory-of-mind/

FARRINGTON, C. A. - RODERICK, M. - ALLENSWORTH, E. - NAGAOKA, J. - KEYES, T. S. - JOHNSON, D. W. - BEECHUM, N. O. (2012). Teaching adolescents to become learners: 
The role of noncognitive factors in shaping school performance; a critical literature review. Chicago: University of Chicago. Consortium on Chicago School Research. https://www. kipp.org/wp-content/uploads/2016/11/Teaching_Adolescents_to_Become_Learners.pdf

FARRINGTON, C. A. (2019): Noncognitive Outcomes Of Liberal Arts Education. The Andrew W. Mellon Foundation. https://mellon.org/media/filer_public/fb/38/fb38e766-2b78-4ee6b869-2b3ee91f3b81/camille_farrington_on_noncognitive_outcomes.pdf

FAYER, S. - LACEY, A. - WATSON, A. (2017): STEM Occupations: Past, Present, And Future, U.S. Bureau of Labor Statistics, Spotlight on Statistics, January. https:/www.bls.gov/spotlight/2017/science-technology-engineering-and-mathematics-stem-occupations-pastpresent-and-future/pdf.

FAZEKAS KÁROLY (2017): Merre halad a kereslet? A nem kognitív készségek felértékelődése. Megjelent: Fazekas Károly-Köllő János (szerk.): Munkaerőpiaci tükör, 2016. MTA Közgazdaság- és Regionális Tudományi Kutatóközpont Közgazdaság-tudományi Intézet, Budapest, 150-159. o. https://www.mtakti.hu/wp-content/uploads/2017/12/MunkaeropiaciTukor2016.pdf.

FAZEKAS KÁROLY (2018): A nem kognitív készségek felértékelődésének hatása a nők munkaerőpiaci helyzetére. Megjelent: Fazekas Károly-Szabó-Morvai Ágnes (szerk.): Munkaerőpiaci tükör, 2017. MTA Közgazdaság- és Regionális Tudományi Kutatóközpont Közgazdaság-tudományi Intézet, Budapest, 122-129. o. https://www.mtakti.hu/wp-content/ uploads/2018/12/mt_2017_hun_egyben.pdf.

GARCIA, E. (2014): The Need to Adress Nonkognitive skills int he Education Policy Agenda). Economic Policy Institute Briefing paper. no. 386. https://www.epi.org/publication/theneed-to-address-noncognitive-skills-in-the-education-policy-agenda/\#epi-toc-7

GAELLE, P.-SANCHEZ PUERTA, M. L.-VALERIO, A.-RAJADEL, T. (2014): STEP Skills Measurement Surveys. Innovative Tools for Assessing Skills. Social Protection and Labor, Discussion Paper, No. 1421. World Bank Group, Washington, DC. https://openknowledge. worldbank.org/handle/10986/19985

GROH, M.-KRISHNAN, N.-MCKENZIE, D. J.-VISHWANATH, T. (2012): Soft skills or hard cash? The Impact of Training and Wage Subsidy Programs on Female Youth Employment in Jordan. World Bank Policy Research Working Paper, No. 6141. http://documents.worldbank.org/curated/en/654491468271825136/pdf/WPS6141.pdf.

GUERRA, N.-MODECKI, K.-CUNNINGHAM, W. (2014): Developing Social-Emotional Skills for the Labor Market: The PRACTICE Model. World Bank, Social Protection and Labor Global Practice Group. Policy Research Working Paper, No. 7123. http://documents.worldbank.org/curated/en/970131468326213915/pdf/WPS7123.pdf.

HANUSHEK, E., - WOESSMANN, L. (2008): The Role of Cognitive Skills in Economic Development. Journal of Economic Literature, 46(3), 607-668. Letöltés: http://www.jstor.org/ stable/27647039

HECKMAN J. J. (2008). Schools, Skills, and Synapses. Economic inquiry, 46(3):289.

HECKMAN, J. J. - HUMPHRIE, J. E. - KAUTZ, T. (2014): The Myth of Achievement Tests. The GED and the Role of Character in American Life. University of Chicago Press.

HECKMAN J. J - RUBINSTEIN Y. (2001): „The Importance of Noncognitive Skills: Lessons from the GED Testing Program". American Economic Review, 91(2):145-149

HECKMAN J. J. - STIXRUD J. - URZUA S. (2006): „The Effects of Cognitive and Noncognitive Abilities on Labor Market Outcomes and Social Behavior." Journal of Labor Economics, 24(3):411-482 
HOESCHLER, P.-BACKES-GELLNER, U. (2018): The Relative Importance of Personal Characteristics for the Hiring of Young Workers. Economics of Education Working Paper Series, No. 142. University of Zurich, Department of Business Administration (IBW) http://repec. business.uzh.ch/RePEc/iso/leadinghouse/0142_lhwpaper.pdf.

HOESCHLER, P.-BALESTRA, S.-BACKES-GELLNER, U. (2018): “The Development of noncognitive skills in adolescence." Economics Letters 163:40-45 http://www.sciencedirect. com/science/article/pii/S0165176517304470

HUMPHRIES J. E. - KOSSE, F. (2017): „On the interpretation of non-cognitive skills - what is being measured and why it matters." Journal of Economic Behavior \& Organization, 136(April):174-185 https://www.sciencedirect.com/science/article/pii/S0167268117300343

HUTSON, M. (2018): Artificial intelligence has learned to probe the minds of other computers, Science, July 27, 2018. https://www.sciencemag.org/news/2018/07/computer-programscan-learn-what-other-programs-are-thinking

KAUTZ, T.-HECKMAN, J. J.-DIRIS, R.-WEEL, B.-BORGHANS, L. (2017): Fostering and Measuring Skills: Improving Cognitive and Non-Cognitive Skills to Promote Lifetime Success, NBER Working Paper, No. 20749. https://www.nber.org/papers/w20749.

LINDQVIST E. - VESTMAN, R. (2011): The Labor Market Returns to Cognitive and Noncognitive Ability: Evidence from the Swedish Enlistment, American Economic Journal: Applied Economics 3(1) :101-28 Letöltve: https://www.aeaweb.org/articles?id=10.1257/app.3.1.101

LU, D. (2019): AI passes theory of mind test by imagining itself in another's shoes, Newscientist, 19. July. https://www.newscientist.com/article/2210508-ai-passes-theory-of-mind-testby-imagining-itself-in-anothers-shoes/\#ixzz60pKpm7Sv

LUNDBERG, S. (2015): Non-Cognitive Skills as Human Capital, IZA. Prepared for the NBER/ CRIW Conference on Education, Skills, and Technical Change, October 16-17.

MORGAN, F. R.-AUTOR, D.-BESSEN, J. E.-BRYNJOLFSSON, E.-CEBRIAN, M.-DEMING, D. J.-FELDMAN, M.-GROH, M.-LOBO, J.-MORO, E.-WANG, D.-YOUN, H.-RAHWAN, I. (2019): Toward understanding the impact of artificial intelligence on labor. Proceedings of the National Academy of Sciences 116(14):6531-6539. https://doi.org/10.1073/ pnas. 1900949116.

NRC (2012): Education for Life and Work: Developing Transferable Knowledge and Skills in the 21st Century. National Research Council, Washington, DC: The National Academies Press. https://doi.org/10.17226/13398.

Olson, S. (2012): Committee on From Neurons to Neighborhoods: Anniversary Workshop; Board on Children, Youth, and Families; Institute of Medicine; National Research Council. National Academies Press, 70. o.

QUINTINI, G. (2015): Enhancing the non-cognitive skills of disconnected youth. OECD, Skills and Work. November 26. https://oecdskillsandwork.wordpress.com/2015/11/26/enhancing-the-non-cognitive-skills-of-disconnected-youth/.

RABINOWITZ, N. C. - PERBET, F. - SONG, H. F. - ZHANG, CH. - ESLAMI, S. M. A. BOTVINICK, M. (2018): Machine Theory of Mind, DeepMind. eprint, Cornell University, (arXiv:1802.07740). https://deepmind.com/research/publications/machine-theory-mind

REVELL, T. (2018): DeepMind AI is learning to understand the 'thoughts' of others. New Scientist, 28 February. https://www.newscientist.com/article/mg23731673-400-deepmind-aiis-learning-to-understand-the-thoughts-of-others/\#ixzz60pJaP12c 
RIVKIN, S.G. - HANUSHEK, E.A. - KAIN, J. F. (2005): „Teachers, schools, and academic achievement." Econometrica 73(2):417-458

ROSEN, J.A. - GLENNIE, E.J. - DALTON, B.W. - LENNON, J.M. - AND BOZICK, R.N. (2010): Noncognitive Skills in the Classroom: New Perspectives on Educational Research. Research Triangle Park, N.C.: RTI International.

SCHANZENBACH, D. W.-NUNN, R.-BAUER, L.-MUMFORD, M.-BREITWIESER, A. (2016): Seven Facts on Noncognitive Skills from Education to the Labor Market. The Hamilton Project,https://www.hamiltonproject.org/assets/files/seven_facts_noncognitive_ skills_education_labor_market.pdf.

SEGAL, C. (2013): Misbehavior, education, and labor market outcomes. Journal of the European Economic Association 11(4):743-779.

SHONKOFF, J. P. - PHILIPS D. A. eds. (2000): From Neurons to Neghborhoods. National Academy of Sciences. 588 o.

SHONKOFF, J. P. (2012): Creating The Future Of Early Childhood Policy And Practice. in: Olson (2012) p35.

THAMPI, A. (2019): Interpretable AI or How I Learned to Stop Worrying and Trust AI. Techniques to build Robust, Unbiased AI Applications. Medium. March 5. https://towardsdatascience.com/interpretable-ai-or-how-i-learned-to-stop-worrying-and-trust-aie61f9e8ee2c2

THIEL H. - THOMSEN, S. L. (2011): Noncognitive Skills in Economics: Models, Measurement, and Empirical Evidence. ZEW Discussion Paper, No.09-076. http://ftp.zew.de/pub/zewdocs/dp/dp09076.pdf

URVASHI, D. -SINGH, A. P. (2017): Non-Cognitive Skills As Essential Life-Skills For School Students. International Journal of Recent Scientific Research, Vol. 8, Issue, 9, pp. 2037820381, September 2017. DOI: http://dx.doi.org/10.24327/ijrsr.2017.0809.0883

WINFIELD A. (2018): Experiments in Artificial Theory of Mind: From Safety to Story-Telling. Front.

Robot. AI 5:75. doi: 10.3389/frobt.2018.00075

YANG, G. Z. - BELLINGHAM, J. - DUPONT, P. E. - FISCHER, P. - FLORIDI, L. - FULL, R. (2018): The grand challenges of science robotics. Sci. Robot. 3: eaar7650. doi: 10.1126/ scirobotics.aar7650

ZERNIKE, K. (2016): Testing for Joy and Grit? Schools Nationwide Push to Measure Students' Emotional Skills. The New York Times. Február 29. https://www.nytimes.com/2016/03/01/ us/testing-for-joy-and-grit-schools-nationwide-push-to-measure-students-emotional-skills.

ZHOU, K. (2016): Non-cognitive skills: Definitions, measurement and malleability. UNESCO Global Education Monitoring Report. ED/GEMR/MRT/2016/P1/5. https://unesdoc.unesco.org/ark:/48223/pf0000245576. 